\title{
METODE PENGAJARAN NAHWU DALAM PENGAJARAN BAHASA ARAB
}

\author{
Ahmad Sehri bin Punawan \\ STAIN Datokarama Palu, Jl. Diponegoro 23 Palu \\ e-mail: a_sehri@gmail.com
}

\begin{abstract}
This article deals with the method of teaching $n a h \square w$ in teaching Arabic. There are two common methods of teaching $n a h \square w$ in Arabic; they are method of alqiyasiyyah (method of sample) and method of alistiqrâiyyah (method of enduction). However, these two methods have their own advantages and disadvantages. Therefore, in teaching $n a h \square w$, the teachers of Arabic should combine the two methods of teaching nahw based on the condition of the students the teachers will teach.

$$
\begin{aligned}
& \text { وثائقية استقرئية تحلية نقدية ـ إن اللغة العربية أمر لا غناء عنه بالنسبة } \\
& \text { للمسلمين ، و لا بستقيم الكلام العربى إلا بالنحو ، و تدريس النحو يحتاج إلى } \\
& \text { عديد من الطرق المناسبة له ـ و كل طريقة من طرق تدريس النحو لا يخلو } \\
& \text { من سلبياتها و من انتقادات موجهة إليها، فالأستاذ الجيد هو الذى يمزج بين } \\
& \text { كل الطرق و انتقائها بما يوافق ميول و رغباب الطلاب مع مراعاة طبيعة } \\
& \text { المادة التدريسية بحيث يشعرون بسولة الدرس و يسره. }
\end{aligned}
$$$$
\text { يتناول هذا البحث أنجع طرق لتعليم النحو فى اللغة العربية وهو دراسة }
$$

Kata Kunci: pengajaran nahwu, metode analogis, metode induktif, i râb, binấ 


\section{PENDAHULUAN}

Sebagai bahasa Agama Islam, bahasa Arab sangat penting dipelajari, khususnya oleh umat Islam. Sebagai salah satu ilmu pokok dalam bahasa Arab, ilmu nahwu tidak dapat diabaikan karena tanpa ilmu nahwu, bahasa Arab akan menjadi kacau-balau dan susunan kata serta kalimatnya akan tidak teratur. Karena itu, dalam mempelajari bahasa Arab, ilmu nahwu penting untuk diketahui.

Ada kesan bahwa ilmu nahwu termasuk ilmu yang susah dimengerti, padahal metode pengajaran ilmu ini cukup banyak dipraktekkan para guru nahwu, tetapi peserta didik tetap saja menghadapi kesulitan dalam mempelajarinya. Oleh karena itu, perlu digunakan metode pengajaran yang cocok dan langkah-langkah yang sesuai serta materi pokok yang harus diprioritaskan lebih dahulu untuk diajarkan pada para pelajar, sehingga dapat memudahkan mereka dalam mempelajari ilmu nahwu.

Terkait dengan hal tersebut, ada sejumlah permasalahan yang perlu dibahas, yaitu: Apa pentingnya ilmu nahwu dipelajari, hususnya oleh para pelajar yang ingin berkomonikasi dengan bahasa Arab?; Apa metode yang perlu digunakan agar para pelajar dapat mempelajari ilmu nahwu dengan mudah? Inilah beberapa pertanyaan penting yang akan dibahas dalam artikel ini.

\section{DEFINISI ILMU NAHWU}

Nahwu menurut bahasa adalah الطريق و الجهة (jalan dan arah) (Abâdî, 1983:394). Menurut Al-Râzî (1992:133), nahwu adalah القصد و. Akan teapi, nahwu menurut istilah ulama klasik adalah terbatas pada pembahasan masalah الإعراب و البناء (i'râb dan binấ), yaitu penentuan baris ujung sebuah kata sesuai dengan posisinya dalam kalimat (الجملة) yang mereka definisikan seperti berikut ini:

$$
\text { النحو قو اعد يعرف بها أحوال الكلمات العربية إعر اباو بناء }
$$

Nahwu adalah aturan-aturan yang dapat mengenal hal ihwal kata-kata bahasa Arab, baik dari segi i'rab maupun bina' (Biek, dkk, t.th.:1). 
Di zaman sekarang ini, setelah berkembangnya penelitian dan pengkajian tentang analisis kebahasaan, para ulama cenderung mengubah dan memperluas pengertian ilmu nahwu, bukan hanya terpusat pada pembahasan i'rab dan bina' bagi sebuah kata, namun dapat pula mencakup pembahasan tentang penjaringan kosakata, pertalian interen antara beberapa kata, penyatuan beberapa kata dalam rentetan bunyi tertentu dan hubungan antara kata-kata yang ada dalam kalimat serta komponen-komponen yang membentuk sebuah ungkapan atau prasa (Husain, 1959:97).

Suatu hal yang tidak dapat dipungkiri ialah perkembangan baru mengenai pengertian baru tentang ilmu nahwu ini tetap mempertahankan urgensi i'rab. Alasannya ialah i'rab merupakan bagian yang tak terpisahkan dalam pembentukan kalimat bahasa Arab, di mana tanpa i'rab, sebuah kalimat bahasa Arab tidak akan sempurna, ciri khas ke-Arabannya akan hilang bila i'rab-nya tidak sempurna.

Kecenderungan sekelompok orang untuk meninggalkan masalah i'rab karena merasa cukup dengan mensukûn pada akhir setiap kata adalah kecenderungan yang tidak dapat diterima. Walaupun demikian, agar tidak terlalu menyulitkan para pelajar, materi ilmu nahwu yang akan diajarkan harus efektif penggunaannya dalam bahasa Arab sehari-hari dan berhubungan secara langsung dengan fungsi dasar nahwu, yaitu penentuan baris ujung kata dan cara membentuk kalimat yang sempurna. Adapun hal-hal yang mendalam mengenai ilmu nahwu ini ditunda lebih dahulu pengajarannya. Beberapa hal dalam pembelajaran ilmu nahwu yang pengajarannya perlu ditunda, antara lain:

- i'râb takdîrî yang ada pada ism maksûr, ism mankûs dan ism yang mudâf pada yâ' al-mutakalimûn;

- i'rab mahallî;

- tasghîr;

- fi’l yang mabnî;

- huruf zâidah;

- ta'ajjub yang bersigat af'al-bih; 
- asmâ' af'âl;

- nâ'ib al-fâ'il yang terdiri atas al-zarf dan al-jâr wa al majrûr;

- jazm al-mudâri' sebagai jawâb shart;

- adawât al-shart yang tidak men-jazm;

- al-istighâthah;

- al-Nadbah.

\section{TUJUAN PENGAJARAN ILMU NAHWU}

Boleh disepakati bahwa pelajaran ilmu nahwu ini adalah bukan sasaran yang menjadi tujuan pembelajaran, tapi ilmu nahwu itu, adalah salah satu sarana untuk membantu kita berbicara dan menulis dengan benar serta meluruskan dan menjaga lidah kita dari kesalahan, juga membantu dalam memaparkan ajaran dengan cermat, mahir dan lancar. Beberapa tujuan mengajarkan ilmu nahwu adalah:

- menjaga dan menghindarkan lisan serta tulisan dari kesalahan berbahasa, disamping menciptakan kebiasaan berbahasa yang fasih. Itulah sebabnya, ulama Arab dan Islam zaman dahulu berupaya untuk merumuskan ilmu nahwu di samping untuk menjaga bahasa Alquran dan Hadis Nabi Muhammad saw;

- membiasakan para pelajar bahasa Arab untuk selalu melakukan pengamatan, berpikir logis dan teratur serta kegunaan lain yang dapat membantu mereka untuk melakukan pengkajian terhadap tata bahasa Arab secara kritis;

- membantu para pelajar untuk memahami ungkapan-ungkapan bahasa Arab sehingga mempercepat pemahaman terhadap maksud pembicaraan dalam bahasa Arab (Shahâțah, 1994:56).

- mengasah otak, mencerahkan perasaan serta mengembangkan khazanah kebahasaan para pelajar;

- memberikan kemampuan pada pelajar untuk menggunakan kaidah bahasa Arab dalam berbagai suasana kebahasaan. Oleh karena itu, hasil yang sangat diharapkan dari pengajaran ilmu nahwu adalah kecakapan para pelajar dalam menerapkan kaidah tersebut dalam gaya-gaya ekspresi bahasa Arab yang digunakan oleh para pelajar bahasa Arab dalam kehidupnya, di samping bermanfaat untuk memahami bahasa klasik yang diwarisi oleh para ulama dari zaman dahulu. 
- kawaid dapat memberikan control yang cermat kepada pelajar saat mengarang sebuah karangan (Ahmad,1984:167-168).

\section{METODE PENGAJARAN NAHWU}

Dalam pandangan lama tentang metode pengajaran nahwu, para pelajar diwajibkan menghafal kaidah, walaupun mereka tidak memahaminya. Akibatnya, mereka tidak berhasil menerapkannya dalam dunia nyata, kaidah-kaidaha yang telah mereka hafal. Hal ini banyak terjadi di pesantren di Indonesia, juga di beberapa negara Arab. Dari sinilah timbul pemikiran untuk mencari solusi bagaimana cara mengatasi problema ini, tentu di antara cara mengatasinya adalah mencari metode terbaik dan termudah untuk menyampaikan pesanpesan ilmu nahwu ke pada pelajar.

Jika diperhatikan metode-metode pengajaran bahasa Arab di negara-negara Arab, juga di beberapa pesantren di Indonesia, baik yang pernah dipraktekkan pada masa lampau, lalu dihentikan atau yang masih digunakan hingga sekarang, juga yang telah diganti dengan metode lain, dapat dikemukkan bahwa metode-metode tersebut dapat dikelompokkani ke dalam dua metode pokok, yaitu metode الاستقرائية (analogis) dan metode (induktif), yang masing-masing akan diuraikan berikut ini.

\section{Metode القياسية (Analogi)}

Metode ini terkadang disebut metode kaidah lalu contoh, adalah metode tertua diterapkan dalam pengajaran ilmu nahwu. Walaupun metode ini adalah yang tertua, namun hingga sekarang masih banyak dipakai di berbagai yayasan pendidikan baik di Arab maupun di Indonesia, khususnya pesantren.

Dalam metode ini, pengajaran dititikberatkan pada penyajian kaidah, pembebanan hafalan kaidah itu atas pelajar, kemudian pemberian contoh-contoh untuk memperjelas maksud dari kaidah tersebut; ini berarti bahwa proses pembelajaran berlangsung dari yang bersifat umum kepada yang bersifat khusus. Ide قيساس ini lahir berdasarkan keinginan agar para pelajar memahami maksud kaidah yang bersifat umum hingga melekat pada benak mereka, itulah sebabnya, guru atau pelajar dituntut untuk menganalogikan contoh 
baru yang masih kabur kepada contoh lain yang sudah jelas, lalu dicocokkan dengan kaidah umum tadi.

Banyak orang yang menantang metode ini dengan alasan bahwa:

- Tampaknya tujuan utama dari metode ini adalah menghafal kaidah tanpa mengindahkan pengembangan kemampuan penerapannya, mungkin saja cocok bagi orang-orang yang secara khusus mengkaji bahasa Arab tetapi tidak cocok bagi anak-anak sekolah yang ilmu nahwu bagi mereka adalah untuk dipraktekkan bukan untuk dihafal.

- Dengan metode ini sering kali para pelajar tidak menghiraukan pelajaran maupun guru, karena sikap pelajar pasif, kalaupun ada pelajar yang berpartisipasi, jumlahnya pelajar tidak banyak.

- Bertentangan dengan prinsip-prinsip pengajaran yang menghendaki dimulai dari yang gampang, lalu bertahap menuju yang susah, dari yang kongkrit pada yang abstrak; sudah tentu bahwa mendahulukan kaidah dari contoh akan menciptakan kepayahan dan kesukaran.

- Pelajar dapat lupa terhadap kaidah yang telah dihafalnya karena mereka sekedar menghafalnya, tanpa memahminya.

- Metode ini banyak ditentang banyak kalangan guru, karena akan mengacaukan perhatian pelajar, juga karena memisahkan antara nahwu dan bahasa, sehingga terkesan bahwa nahwu sebagai sasaran, bukan sebagai sarana untuk memperbaiki ungkapan bahasa.

Perlu digarisbawahi bahwa buku-buku pelajaran nahwu zaman dahulu mengikuti jalannya metode ini, seperti dalam kitab alAjrûmiyyah, al-Nahw al-wâf karangan Abbâs $\mathrm{H} \square$ asan, Jâmi' al-Durûs al-'Arabiyyah oleh Al-Gulayaini, kitab Qawâ'id al-Lughah al'Arabiyyah yang disusun oleh Hafni Beik Nasib, dkk. serta masih banyak buku lain yang seirama dengan buku-buku di atas.

\section{Metode استقرائية (Induksi)}

Metode ini kadang diberi nama استنباطية ,استنتاجية atau metode Herbart Karen mengikuti lima langkah yang harus dilakukan dalam mengajar sebagaimana yang ditetapkan oleh Johan Priedrich Herbart (Ahmad,1984:191). Pada mulanya metode ini masuk ke dunia Arab setelah adanya ajakan dari delegasi misi pengajaran dari Eropa pada awal abad XX M., di mana gaya pengajaran dalam metode ini adalah 
kebalikan dari metode قياسية, karena metode ini didasarkan pada penyajian contoh-contoh terlebih dahulu lalu contoh-contoh itu didiskusikan dengan para pelajar, dibanding-bandingkan, da dirumuskan kaidahnya kemudian diberikan latihan kepada para pelajar. Metode ini dimulai dari yang khusus untuk mencapai kaidah yang bersifat umum, sementara قياسية dari yang umum kepada yang khusus.

Para pendukung metode ini berpandangan bahwa metode semacam ini adalah metode yang alami karena para pelajar melalui contoh-contoh, dapat untuk mencapai suatu ilmu, menyingkap ketidak tahuan, memberikan pencerahan pada yang tidak jelas dengan cara mengenal unsure-unsurnya, mengumpulkan kosakata dan menggabungkan sesuatu dengan sejenisnya; hal ini dilakukan secara bertahap hingga sampai pada suatu rumusan kaidah yang bersifat umum atau aturan yang komprehensif.

Para pendukung metode ini berpendapat bahwa dengan metode ini pelajar akan bersikap aktif, sedangkan guru hanya sebagai pengarah dan pemandu. Jadi, para pelajarlah yang aktif mencari untuk mendapatkan rumusan kaidah yang diinginkan setelah mendiskusikan dan menghubungkan serta membanding-bandingkan contoh-contoh yang ada; para pelajar pulalah yang memecahkan masalah. Tegasnya, para pelajar disibukkan dengan kegiatan diskusi sehingga tidak ada kesempatan untuk diam atau mengabaikan pelajaran.

Namun demikian, bagimana pun juga metode ini menurut penulis, tidak lepas dari kelemahan-kelemahan di antaranya ialah metode ini lambat dan tidak efektif dalam menyampaikan informasi, contoh-contoh yang dipaparkan guru pun terbatas serta adanya keinginan untuk segera sampai pada perumusan kaidah. Tetapi walaupun demikian, banyak negara Arab yang menerapkan metode ini di sekolah-sekolah. Di samping itu, buku-buku sekarang yang disusun sesuai dengan metode ini telah banyak, seperti: kitab al-Nah $\square w$ alWâdi' yang dikarang oleh 'Alî al-Jârim dan Mus $\square$ tafầ Amîn juga alArabiyyah li al-Nâshi'în.

Metode استقر ائية ini dapat dibagi ke dalam dua bagian, yaitu: (1) metode contoh, yaitu contoh-contoh yang tidak punya kaitan dengan yang lain, lalu kaidah; dan (2) metode teks utuh, yaitu suatu teks yang mempunyai makna komplit, contoh, dan kaidah. 


\section{Metode Contoh}

Disebut juga metode contoh buatan, mandiri, terserak atau terpotong; penamaan ini timbul karena contoh-contoh itu terserak dan terpotong-potong; terpotong-potong diambil dari berbagai sumber yang tidak satu arah.

\section{Kelebihan metode contoh}

Para pendukung metode ini berpendapat bahwa metode ini memberikan peluang bagi seorang guru untuk memilih contoh-contoh secara leluasa, juga dapat membantu guru beserta para pelajar untuk mempercepat jalannya pembelajaran.

Mereka berpandangan bahwa metode ini mudah digunakan sehingga sangat membantu pembelajaran ilmu nahwu, di mana seorang pelajar yang benar-benar memahami kaidah, lidahnya akan lebih fasih dan orang yang menggali kaidah dari contoh-contoh yang disebutkan sebelumnya di samping akan dapat membantu guru untuk menghabiskan semua topik-topik inti yang ada pada silabinya, ia dapat pula mengatasi problema yang ditimbulkan oleh kurikulum.

\section{Metode Teks Utuh}

Metode ini sering disebut metode konteks bersambung, teks sempurna atau metode resafel, karena metode ini adalah hasil dari perubahan metode pengajaran sebelumnya. Metode ini berkonsentrasi pada penyajian sebuah teks atau karangan utuh yang diambil dari buku-buku bacaan, teks-teks sastra, materi sejarah, surat kabar harian atau majalah mingguan atau sejenisnya, diutamakan teks-teks yang memuat peristiwa-peristiwa yang masih hangat dalam benak para pelajar.

Kewajiban guru dalam menerapkan metode ini adalah menjalankan teks itu, lalu membahas bagaimana membahas topik bacaan (قراءة), kemudian mengambil contoh teks itu yang dapat dijadikan dasar sebagai materi pelajaran lalu meneruskan langkahlangkah yang harus diambil sesuai metode استقر ائية ال.

\section{Kelebihan Metode Teks Utuh}

Para pendukung metode ini berpandangan bahwa pengajaran nahwu melalui pendekatan celah-celah bahasa akan membawa kepada kemantapan, pelajar pun akan merasakan adanya kontak antara bahasa 
dengan kehidupannya, sehingga mereka cinta kepada nahwu bukan sebaliknya. Disamping pengintegrasian antara paparan bahasa (تعبير) yang fasih dengan ilmu nahwu akan memantapkan anak-anak pada bahasa dan gaya-gayanya termasuk cara i'rab-nya. Cara ini akan menghindarkan guru dari beban menyuruh anak didiknya untuk menghafal apa yang mereka tidak mengerti.

\section{Kelemahan Metode Teks Utuh}

Metode teks utuh memiliki kelemahan, di antaranya yaitu:

- Sebagian guru merasa susah mencari atau membuat teks yang dapat menampung semua persoalan sub materi pelajaran, sebab kadangkadang guru menghadapi kesulitan menghadapinya. Akibatnya, terkadang bahasanya banyak yang rusak.

- Untuk menyentuh semua sisi kaidah yang diinginkan, biasanya guru terpaksa membuat teks yang sangat panjang hingga satu halaman atau lebih. Akibatnya, guru akan menghadapi dua hal dilematis:

- Guru membahas teks yang panjang tadi dengan sempurna, dari pendahuluan, membaca mendiskusikan dengan pelajar, menjelaskan maknanya hingga menyeleksi contoh-contoh yang diinginkan. Dalam hal ini, waktu tidak cukup untuk menjelaskan pelajaran. Waktu yang disiapkan untuk melakukan latihan jadi berkurang, belum lagi para pelajar tidak mememiliki waktu yang cukup untuk meyusun kawaid yang benar.

- Atau guru mengabaikan teks dan langsung menyeleksi contohcontoh, menjelaskan dan mendiskusikannya dengan singkat tanpa memuaskan peserta didik. Dalam hal ini, guru telah menyimpang dari metode pengajaran yang ideal, yaitu metode yang dapat mengasosiasikan antara diskusi nahwu yang memadai dan latihannya yang memuaskan serta pendidikan yang menghendaki bahwa kawaid harus diajarkan di bawah naungan teks bahasa sastra.

Setelah pemaparan tentang metode-metode yang pernah diguanakan dalam pengajaran nahwu, serta mengingat sedikitnya penelitian yang dilakukan untuk menemukan metode yang tepat dalam memgajarkan nahwu maka tidaklah gampang bagi kita untuk melebihkan salah satu metode tertentu dengan meremehkan metode 
yang lain. Setiap metode memeiliki pendukung dan penentang, memiliki kelemahan dan kelebihan. Dari sinilah mungkin sangat diperlukan adanya penelitian lapangan yang intensif untuk memilih atau menciptakan metode yang lebih cocok untuk diterapkan. Tentunya tidak boleh memutuskan keefektifan salah satu metode itu kecuali melalui eksperimen di lapangan yang dilakukan oleh orangorang yang menguasai metode pengajaran bahasa Arab.

Perlu dicatat bahwa seorang guru yang dapat dinilai berhasil di sini adalah seorang guru yang mampu mengambil untung dari keunggulan-keunggulan dari dua metode tadi, الاستقرائية dan yaitu guru yang mengetahui kapan dan di mana masing-masing metode itu harus digunakan kemudian diaplikasikan sesuai dengan pengetahuannya, mengingat bahwa kawaid, aturan dan prinsip apapun tak akan ada gunanya apabila seorang guru tidak mengetahui bagaimana penerapannya di lapangan.

\section{LANGKAH-LANGKAH PENGAJARAN ILMU NAHWU}

Kebanyakan buku yang disusun akhir-akhir ini mengikuti metode dengan dua cabangnya seperti yang telah dipaparkan di atas. Oleh sebab itu, dalam langkah pengajaran akan dibatasi pada metode pengajaran System Herbart sebagai contoh yang baik bagi metode استقرائية.

Metode ini dilakukan melalui tahapan-tahapan sebagai berikut:

- Tahap persiapan (pendahuluan)

Pada langkah persiapan, guru harus mempersiapkan secara matang terhadap materi pelajaran yang akan disajikan, selanjutnya guru memulai dengan pertanyaan-pertanyaan pendahuluan mengenai teks atau contoh-contoh dalam bagian kawaid yang telah dipelajari sebelumnya yang berhubungan dengan topic pelajaran yang akan diajarkan sekarang, artinya guru harus mengadakan apersepsi terhadap pelajaran yang lalu dengan pelajaran yang akan diberikan, apa lagi hubungan antara materi pelajaran kawaid itu satu sama lainnya adalah kuat.

Dalam pendahuluan ini, guru harus menitikberatkan pada penjelasan sisi makna, dimana para pelajar harus diberi pemahaman الاسم ، الفعل ، الحرف ، المبتدأ ، الخبر ، الاستثناء ، التفضيل ، makna mengenai 
serta istilah-istilah lain yang ada dalam ilmu nahwu.

Langkah pendahuluan ini dimaksudkan untuk menarik perhatian dan konsentrasi para pelajar agar mereka dengan mudah menerima topik pelajaran baru.

- Tahap penyajian contoh atau teks sempurna

Setelah diadakan apersepsi, langkah berikutnya guru mulai memberikan materi pelajaran dengan diawali dari hal-hal yang mudah menuju kepada materi yang sulit dan dari kongkrit kepada yang abstrak. Oleh karena itu, dalam metode contoh ini, guru menulis contoh-contoh itu di papan tulis, baik contoh yang dibuat oleh guru sendiri maupun para pelajar setelah mereka menerima beberapa pertanyaan dari gurunya. Tidak ada salahnya jika guru ingin menulis beberapa contoh tambahan pada kertas terpisah lalu dibagikan kepada para pelajar.

Adapun dalam metode teks sempurna, guru menulis teks itu di papan tulis, atau telah ditulis sebelumnya di kertas, lalu dibagikan kepada peserta didik. Setelah itu, guru menjelaskan teks itu sebagaimana ia menjelaskan materi قراءة yaitu dengan pendahuluan, bacaan, dan menjelaskan makna kosakata kemudian mendiskusikan makna umum dari teks tadi. Karena guru harus mengutip contohcontoh dari teks yang ada, guru mengajukan pertanyaan kepada para pelajar yang jawabannya adalah kalimat yang dapat menghasilkan rumusan kaidah, kemudian contoh yang dijawab oleh pelajar ditulis di atas papan tulis sambil menggarisbawahi kata yang diinginkan atau ditulis dengan tulisan berwarna, selanjutnya memberi baris akhir.

Contoh-contoh yang diajukan jumlahnya harus cukup, karena juika contohnya terbatas maka akan mengurangi bahkan akan menghilangkan bobot kaidah yang akan dibuat. Disamping itu, contoh yang tidak cukup akan mengakibatkan kesalahan, karena kaidah yang akan dibuat dapat dilakukan dengan cara tergesa-gesa. Sebaiknya contoh yang memadai di samping akan memperkuat nilai kaidah itu sendiri, ia akan memberi kesan yang mendalam pada benak peserta didik. 
- Tahap menimbang dan mempertemukan

Setelah proses penyajian selesai, guru harus mengadakan asosiasi dan menggabungkan pelajaran lalu dengan pelajaran baru, sehingga pelajaran mempunyai hubungan erat.

Dalam hal ini, guru berupaya mempertemukan antara bagianbagian dari teks atau contoh-contoh yang telah disajikan itu, supaya peserta didik mengetahui titik persamaan dan perbedaan antara bagian atau contoh itu.

Semakin cermat guru mempertemukan persamaan itu, semakin besar pula harapan untuk mencapai target, juga kesuksesan mata pelajaran bergantung kepada kepandaian seorang guru dalam mengasosiasikan pelajaran lama dengan pelajaran baru sebab guru berperan sebagai pengarah, pemandu, dan pengoreksi. Adapun pelajar harus berperan sebagai tim pencari titik persamaan dan perbedaan, membanding-bandingkan dan mempertemukan, kemudian memberi kesimpulan dalam bentuk perumusan kaidah.

- Tahap perumusan kaidah (pengorganisasian bahan)

Selanjutnya, mengorganisir bahan yang baru dengan yang lama sebagai suatu hasil hubungan asosiasi yang menjadi suatu sistem pengertian yang kompak dan utuh. Bila seorang guru telah berhasil menjalankan langkah-langkah yang sebelumnya maka akan mudah bagi para pelajar untuk menyusun dan mengorganisir pengetahuan dan pengalaman yang diperoleh dari beberapa proses di atas dalam bentuk perumusan kaidah, dan bila ada peristilahan nahwu yang mereka belum ketahui maka guru harus mengajarkannya dengan singkat; setelah itu guru harus menulis kaidah yang telah dirancang oleh para pelajar di atas papan tulis dihadapkan pada contohnya, dalam perumusan ini harus melibatkan semua pelajar atau paling tidak mayoritas mereka, agar kaidah menjadi lebih padat dan komprehensif. Setelah itu, guru membacakan kaidah rumusan itu, kemudian menugaskan para pelajar untuk membacanya secara bergiliran.

- Tahap aplikasi

Sebagai langkah akhir, guru memberikan soal-soal berupa latihan dan mempraktekkan hasil pelajaran yang telah diberikan. Tegasnya, untuk memantapkan rumusan kaidah yang telah dibuat, guru harus memberikan latihan kepada para pelajar. Hal ini 
dimaksudkan untuk mengukur sisi kelemahan para pelajar untuk diperbaiki; mungkin itulah sebabnya sehingga buku-buku pelajaran nahwu yang banyak disusun akhir-akhir ini pada setiap akhir pemberian materi pelajaran harus diikuti dengan latihan-latihan yangs disusun secara bervariasi, baik dalam bentuk soal maupun materi pertanyaannya, sehingga penguasaan para pelajar terhadap kaidah semakin meresap dan mantap.

\section{PENUTUP}

Setelah dikaji dan dibahas beberapa metode pengajaran nahwu dalam bahasa Arab, dalam tulisan ini dapat disimpulkan sebagai berikut.

Dalam ilmu pengajaran ilmu nahwu harus ada inovasi, yaitu objek kajiannya harus diperluas dan ada beberapa materi pengajarannya yang harus didahulukan dan menunda materi yang lain, yaitu materi yang kurang menyentuh bahasa sehari-hari bagi para pelajar.

Untuk menghindari kesalahan dalam penuturan bahasa Arab maka ilmu nahwu sebagai kaidah yang mengatur cara menyusun kosakata bahasa Arab dengan benar, harus dipelajari, khususnya oleh para pelajar yang ingin berkomunikasi dalam bahasa Arab.

Ada beberapa metode dalam pengajaran nahwu, masing-masing metode tersebut ada pendukungnya dan penentangnya; belum bisa diunggulkan salah satu metode atas yang lainnya. Oleh sebab itu, diperlukan penelitian intensif di lapangan oleh orang-orang spesialis di bidang ini agar dapat ditemukan metode yang cocok untuk pengajaran nahwu.

Agar para pelajar dapat memahami ilmu nahwu secara lebih mudah dibutuhkan metode pengajaran yang cocok untuk menanggulangi kesulitan mereka, yaitu dengan tidak terpaku kepada satu metode tertentu saja, tetapi harus menggabungkan semua metode sesuai dengan kebutuhan situasi dan kondisi para pelajar.

\section{DAFTAR PUSTAKA}

Abâdî, al-Shaykh Majd al-Dîn Muh ammad bin Ya'qûb al-Fayrûz. 1983. AlQâmûs al-Muhît. Jilid V. Beirut: Dârl al-Fikr.

Ah mad, Muh ammad 'Abd al-Qadîr. 1984. T urûq al-Ta'lîm al-Lughah al'Arabiyah. Cairo: Maktabah al-Nahd\}ah al-Misriyah. 
Jurnal Hunafa, Vol. 7, No.1, April 2010:47-60

Biek, Hifniy dkk. T.th. Qawâ'id al-Lughah al-'Arabiyah. Surabaya: Maktabah al-Hidayah.

Husayn, T âha. 1959. Mushkilat al-I'râb, Majallah Majma' al-Lughah al'Arabiyyah. Cairo: al-Hay'ah al-Âmmah li Shu'ûn al-Mata bi' alAmîriyah.

al-Râzî, al-Imâm Muh ammad bin Abî Bakr 'Abd al-Qadîr. 1992. Mukhtâr alShah $h$ ah. Cet. I. Beirut: Dârl al-Kutub al-'Ilmiyah.

Shahațah, Hasan. 1994. Ta'lîm al-Dîn al-Islâmî bayn al-Nazariyyah wa alTat\}bîq. T.tp.: Maktabah al-Dâr al-'Arabiyyah li al-Kitâb. 